\title{
Nagysejtes neuroendocrin carcinoma - a kórisme és a kezelés nehézségei
}

\author{
Zombori Tamás dr. ${ }^{1}$ - Juhász-Nagy Gréta ${ }^{1}$ \\ Tiszlavicz László dr. ${ }^{1}$ - Cserni Gábor dr. ${ }^{1}$ - Furák József dr. ${ }^{2}$ \\ Szalontai Klára dr. ${ }^{3}$ - Pálföldi Regina $d r .^{3}$ \\ ${ }^{1}$ Szegedi Tudományegyetem, Általános Orvostudományi Kar, Pathologiai Intézet, Szeged
${ }^{2}$ Szegedi Tudományegyetem, Általános Orvostudományi Kar, Sebészeti Klinika, Szeged
${ }^{3}$ Csongrád Megyei Mellkasi Betegségek Szakkórháza, Deszk
}

A rosszul differenciált neuroendocrin tumorok közé tartozik a jól ismert kissejtes carcinoma, valamint a ritka nagysejtes neuroendocrin carcinoma. A két daganat hasonló morfológiai képe, a betegség agresszív viselkedése, illetve a vitatott kezelési ajánlások miatt a diagnózis felállítása és a terápia megválasztása multidiszciplináris megközelítést igényel. Bal oldali fejfájás, hányinger, homályos látás miatt került felvételre az 52 éves nőbeteg. A képalkotó vizsgálat bal occipitalisan, illetve a kisagyban metasztázisra gyanús képletet ábrázolt. Az idegsebészeten mindkét tumort eltávolították. A szövettani vizsgálat neuroendocrin carcinoma agyi áttétét igazolta. A mellkas CT-vizsgálata a bal tüdőben kontrasztanyagot halmozó képletet igazolt. A bronchoszkópos biopsziás minta nagysejtes neuroendocrin carcinomát kórismézett. Posztoperatív koponyabesugárzást és a kissejtes tüdőrák protokollja szerinti kemoterápiát alkalmaztak. Rövidesen progresszió és atelectasia miatt mellkasbesugárzás kezdődött, amelyet ismételt agyi áttétek miatt meg kellett szakítani. A kemoterápiát a nem kissejtes tüdőrák protokollja alapján folytatták. Három hónap után mellkasi progresszió, kisagyi és csontáttétek jelentkeztek. A beteg 14 hónap kezelés után elhunyt. A nagysejtes neuroendocrin carcinoma rossz prognózisú, az esetek 25-50\%-ában agyi áttétet adó tüdődaganat. A korai stádiumú nagysejtes neuroendocrin carcinoma esetében a sebészeti kezelés szerepe elsődleges, az adjuváns kemoterápia mérlegelendő. A kemoterápia során a nem kissejtes tüdőrák protokollja az elfogadott, de az irodalmi adatok alapján a kissejtes carcinoma kezelési sémája is mérlegelhető.

Orv Hetil. 2020; 161(8): 313-319.

Kulcsszavak: tüdőrák, nagysejtes neuroendocrin carcinoma, kissejtes carcinoma, differenciáldiagnosztika, kezelési kihívások

\section{Large-cell neuroendocrine carcinoma of the lung - challenges of diagnosis and treatment}

Small-cell lung carcinoma (SCLC) and the rare large-cell neuroendocrine carcinoma belong to the high grade pulmonary neuroendocrine carcinomas. Making the correct diagnosis and selection of treatment modalities require multidisciplinary meetings due to the morphological overlaps, aggressive behaviour and debated therapeutic guidelines of these entities. A 52-year-old woman was admitted to the hospital because of headache, nausea and tenebrous vision. The CT revealed metastatic tumour mass in the occipital lobe and in the cerebellum. Both tumours were removed and resulted in histological diagnosis of metastatic neuroendocrine carcinoma. Chest X-ray established contrast-enhancing lesion in the left lung. Bronchoscopy was performed and histological examination revealed large-cell neuroendocrine carcinoma. Postoperative skull irradiation and small-cell lung cancer chemotherapy protocol were utilized. Due to atelectasis and progression, chest irradiation was initiated, which was interrupted because of novel brain metastases. Further chemotherapy followed the non-small-cell lung cancer protocol. After 3 months, thoracic progression, brain and disseminated bone metastases were diagnosed. After a 14-month-long therapy, the patient deceased. Large-cell neuroendocrine carcinoma has a poor prognosis, the incidence of brain metastasis is $25-50 \%$. In early stage large-cell neuroendocrine carcinoma, lobectomy is the standard treatment and adjuvant chemotherapy should also be considered. Although the non-small-cell lung cancer chemotherapy protocol is approved widely in the treatment of large-cell neuroendocrine carcinoma, the utility of SCLC scheme has also been suggested.

Keywords: lung tumour, large-cell neuroendocrine carcinoma, small-cell lung cancer, differential diagnosis, challenges of treatment 
Zombori T, Juhász-Nagy G, Tiszlavicz L, Cserni G, Furák J, Szalontai K, Pálföldi R. [Large-cell neuroendocrine carcinoma of the lung - challenges of diagnosis and treatment]. Orv Hetil. 2020; 161(8): 313-319.

(Beérkezett: 2019. július 15.; elfogadva: 2019. szeptember 27.)

\section{Rövidítések}

ALK $=$ (anaplastic lymphoma kinase $)$ anaplasticus lymphoma kináz; $\mathrm{CBP}=($ carboplatin $)$ karboplatin; CD56 $=($ cluster of differentiation 56) differenciációs klaszter-56; CI = (confidence interval) konfidenciaintervallum; $\mathrm{CK}=$ citokeratin; $\mathrm{CK}$ $\mathrm{AE} 1 / \mathrm{AE} 3$ = páncitokeratin; $\mathrm{COPD}=($ chronic obstructive pulmonary disease) krónikus obstruktív tüdőbetegség; $\mathrm{CT}=$ (computed tomography) számítógépes tomográfia; FGFRl = (fibroblast growth factor receptor 1) fibroblastnövekedési faktor receptor- 1 ; KEAPl $=($ Kelch-like ECH-associated protein 1) Kelch-féle ECH-asszociált fehérje-1; Ki67 = KI67-antigén; KRAS $=$ (Kirsten rat sarcoma viral oncogene $)$ a Kirsten-patkány-szarkóma virális onkogénje; LCNEC = (large-cell neuroendocrine carcinoma) nagysejtes neuroendocrin carcinoma; $\mathrm{MR}=$ (magnetic resonance) mágneses rezonancia; $\mathrm{MYCL}=$ L-myc-1 protoonkogén protein; NCCN $=($ National Comprehensive Cancer Network) Nemzeti Átfogó Rák Hálózat (Egyesült Államok); NFE2L2 = nuclear factor erythroid 2-related factor $2 ; \mathrm{NNL}=$ nagy nagyítású látótér $(40 \times) ; \mathrm{NSCLC}=($ nonsmall-cell lung cancer) nem kissejtes tüdőrák; $\mathrm{NVB}=$ vinorelbin; $\mathrm{OS}=($ overall survival $)$ teljes túlélés; $\mathrm{p} 53=$ tumorprotein p53; PDl $=($ programmed cell death 1$)$ programozott sejthalál-1; PDLl $=($ programmed cell death ligand 1$)$ programozott sejthalál ligandum-1; PTEN $=$ (phosphatase and tensin homo$\log$ ) foszfatáz- és tenzinhomológ; RBl = retinoblastomaprotein; $\mathrm{RTG}=$ röntgen; SCLC $=($ small-cell lung cancer $)$ kissejtes tüdőrák; $\mathrm{SOX} 2=\mathrm{SRY}$ (sex determining region Y)-box 2; STK11 = (serine/threonine kinase 11$)$ szerin/treonin kináz-11; TTFl $=($ thyroid transcription factor 1$)$ pajzsmirigy-transzkripciós faktor- $1 ; \mathrm{Vp}=$ etopozid

A tüdőrák hazánkban továbbra is a leggyakoribb rosszindulatú megbetegedések közé tartozik, melyek mintegy negyedét neuroendocrin tumorok alkotják. Ezen belül a jól ismert kissejtes carcinoma (SCLC) a leggyakoribb, de emellett nemritkán a nagysejtes neuroendocrin carcinomával (LCNEC) is találkozunk. A hasonló, rosszul differenciált morfológia, az agresszív viselkedés és a vitatott szakirodalmi kezelési ajánlások miatt a betegség pontos kórisméjéhez elengedhetetlen a multidiszciplináris megközelítés, melyet centrumunk anyagából egy eset ismertetésén keresztül mutatunk be.

\section{Esetismertetés}

Az 52 éves nőbeteg bal oldali halántéktáji, illetve tarkótáji fejfájás, hányinger, homályos látás miatt került a sürgősségi osztályra 2018 júniusában. Anamnézisében pánikbetegség, mitralis prolapsus és P4-es citológia miatti hysterectomia, valamint 36 csomagév dohányzás szere- pel. A koponya-CT- és -MR-vizsgálat bal oldalon occipitalisan egy $15 \times 16 \times 14 \mathrm{~mm}$-es, illetve a kisagyban egy $35 \times 30 \times 25$ mm-es, gyưrüszerűen halmozó, metasztázisra gyanús képletet ábrázolt $(1 / A$ ábra). Az idegsebészeten mindkét tumort eltávolították; a szövettani vizsgálat neuroendocrin carcinoma agyi áttétét igazolta, a primer tumor lokalizációját illetően a tüdőt vetették fel. Mellkasi, hasi és kismedencei CT-vizsgálat a bal tüdő 5-ös szegmentumában egy $30 \mathrm{~mm}$-es, spikulált kontúrú, kontrasztanyagot halmozó képletet igazolt ( $1 / B$ ábra), emellett a bal mellékvesében merült fel a metasztázis lehetősége. A csontszcintigráfián kóros eltérést nem írtak le. Mindezek alapján tüdőtumort véleményeztünk, melynek stádiuma: T2aN0Mlc. A neuroonkoteam a posztoperatív koponyabesugárzás (teljes agy + tumorágy) mellett foglalt állást, melyet a beteg szövődménymentesen megkapott $(15 \times 2,3+15 \times 0,7 \mathrm{~Gy})$. A pulmonológiai onkoteam karboplatin-etopozid (CBP-Vp) kemoterápiás kezelést javasolt. Ebból két ciklust kapott meg a beteg, majd a harmadik ciklus elötti mellkasi röntgen (RTG)-felvételen progressziót detektáltunk. Urgens mellkas-CT történt, amelyen a bal felső lebenyben egy $5 \mathrm{~cm}$ széles atelectasiát fedeztünk fel ( $1 / C$ ábra). Bronchoszkópiát végeztünk, melynek során a bal felső lebenyhörgőt az eredése után közel 1 cm-rel endobronchialisan terjedő tumor zárta el, a bal alsó lebeny bemenete kissé komprimált, de a distalis szájadékok szabadok voltak ( $1 / D$ ábra). A tumorszövetből mintavétel (excízió + lenyomat) történt. A szövettani vizsgálat során tömör fészkes, necroticus carcinomát észleltünk. A sejtfészkek széli részein a tumorsejtek kerítésléc-szerüen helyezkedtek el, illetve prominens volt a tumoros rozetta képződése (2/A ábra). A sejtmagokban a kromatin nyitott volt, és feltünő magvacskák mutatkoztak. Tíz, nagy nagyítású látótérben (NNL) 12 mitózist figyelhettünk meg. A daganatszövet élénk citokeratin-7 citoplazmatikus és diffúz CD56-membrán-pozitivitást mutatott (2/B és 2/C ábra). Ezenfelül diffúz TTFl nukleáris és fokális szinaptofizin citoplazmatikus pozitivitást észleltünk. A Ki67-expresszió mintegy 60\%-os proliferációs aktivitást jelzett (2/D ábra). A látott hisztológiai kép és az immunfenotípus alapján LCNEC-t kórisméztünk. A klinikusok a kezdeti - agyi - szövettanmintát újraértékeltették. Az agyi áttét szövettani képe megegyezett a tüdőben észlelt daganatéval, aminek alapján a tüdőeredetű áttét bizonyítást nyert. A bal felső lebenyhörgőt elzáró és atelectasiát okozó tumor miatt mellkasi sugárkezelést kezdtünk, de hányinger, hányás és időszakos fejfájás miatt kontroll-koponya-MR-t kértünk, mely a 

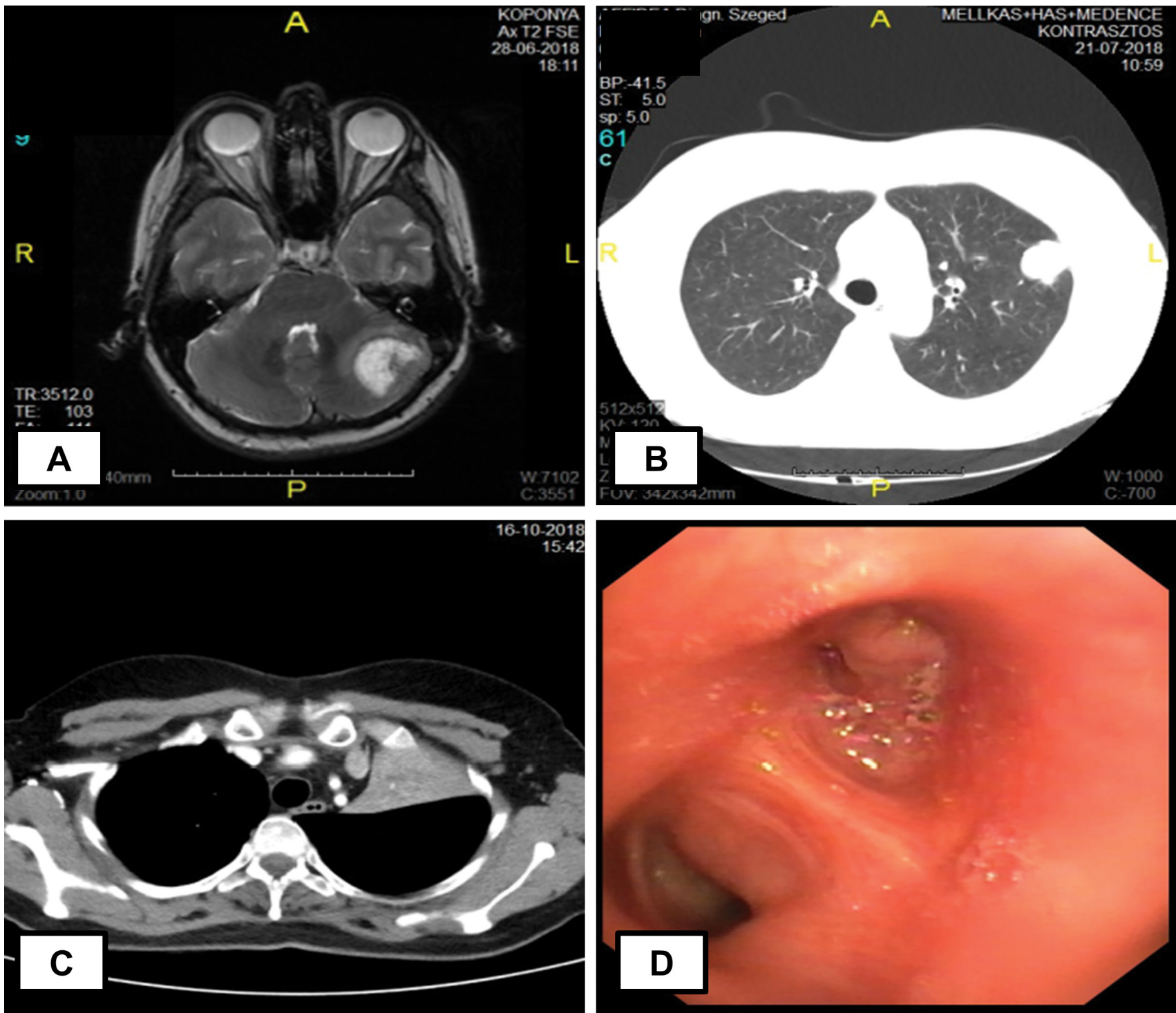

1. ábra A) Koponya-MR-felvételen a bal kisagyféltekében gyúrúszerú halmozást mutató terime észlelhető; B) Mellkas-CT-felvételen a bal tüdő 5-ös szegmen-
tumában egy $30 \mathrm{~mm}$-es spikulált kontúrú, kontrasztanyagot halmozó képlet azonosítható; C) Mellkas-CT-képen a bal felső tüdőlebeny területén ki-
terjedt atelectasia látható; D) Bronchoszkópos felvételen látható, hogy a bal felső lebenyhörgót tumor zárja el, a bal alsó lebeny bemenete kissé
komprimált
CT = számítógépes tomográfia, $\mathrm{MR}$ = mágneses rezonancia

mütéti területen 2, recidivára utaló képletet ábrázolt. Ezért a mellkasi sugárkezelést átmenetileg felfüggesztettük $(3 \times 1,8$ Gy-t kapott meg a beteg). Az idegsebészeti konzílium mútét mellett döntött, melynek során craniotomiás feltárásból a recidív képleteket eltávolították. A mütét után a mellkasi sugárkezelést komplettáltuk $(5 \times 4$ Gy-t kapott még meg a beteg), és kontroll-mellkasRTG-vizsgálaton az atelectasia oldódását észleltük. Tekintettel arra, hogy a szövettani vizsgálat LCNEC-t igazolt, valamint arra, hogy a korábban alkalmazott kissejtes kemoterápiás protokoll mellett progressziót észleltünk, az onkoteam-konzílium a nem kissejtes tüdőtumor protokollja szerinti kemoterápiás kezelés mellett döntött (karboplatin-paklitaxel-bevacizumab). Ez alapján 4 ciklust kapott meg a beteg. A kontroll-mellkas-CT szerint a bal oldali perifériás tüdőtumor mérete közel stacioner, az atelectasia kis kiterjedésü volt, illetve a koponya-MR és a csontszcintigráfia metasztázist nem igazolt, ezért az obszerváció mellett döntöttünk.

Három hónappal később a beteg fogyás, fejfájás, járásbizonytalanság, szédülés miatt került ismételten osztályunkra. A koponya-CT-vizsgálat multiplex agyi, illetve kisagyi metasztázisokat igazolt, melyek miatt kombinált dehidráló kezelés indult. Emellett a mellkas-RTG-vizsgálat pulmonalis progressziót mutatott ki. Az idegsebészet a konzervatív terápia mellett foglalt állást, a sugárterápiás konzílium döntése alapján már sugártartalék nem volt a koponya vonatkozásában. Ezért a pulmonológiai onkoteam szisztémás kezelést (pemetrexed) javasolt. Szomatosztatinreceptor-meghatározás történt, melynek 

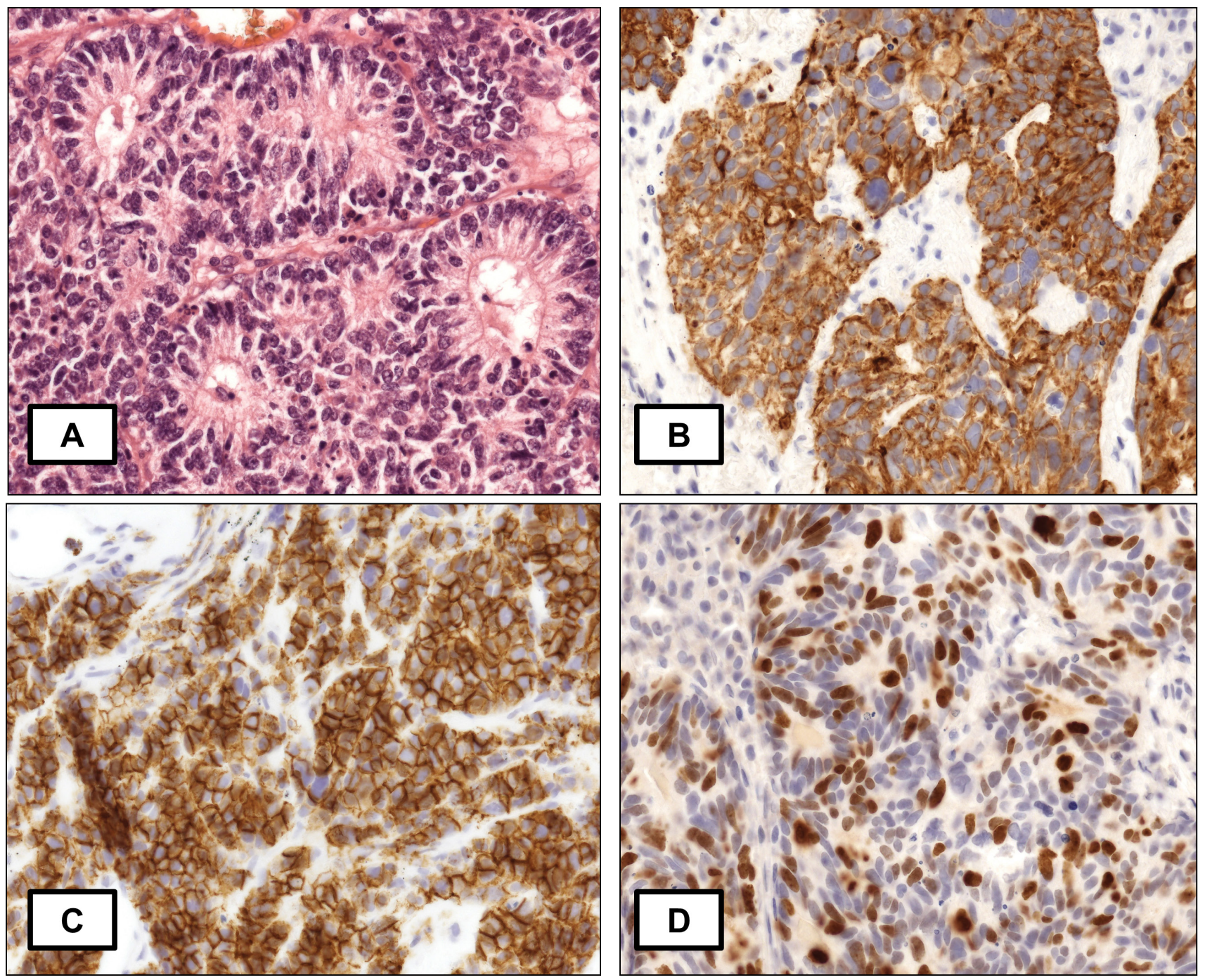

2. ábra

A) Rozettaképződmények a hörgőbiopsziás anyagban (HE, 40×); B) Diffúz citoplazmatikus citokeratin-7-expresszió (CK7, 40×); C) Diffúz CD56 membrán-expresszió (CD56, 40×); D) A proliferációs ráta mintegy 60\% (Ki67, 40×

CD56 = differenciációs klaszter-56, CK7 = citokeratin-7, HE = hematoxilin-eozin; Ki67 = KI67-antigén

során csak citoplazmatikus festődés volt igazolható. Ez kis klinikai hatékonyságot vetített előre, emiatt a szomatosztatinreceptor-antagonista kezelést nem forszíroztuk. Az első ciklus Alimta (pemetrexed)-kezelés után fokozatos klinikai és radiológiai progressziót észleltünk. A bal csípőtáji fájdalom hátterében a bal oldali csípőlapát területén elmozdulással nem járó törés igazolódott. Célzott RTG-felvétel alapján többszörös csontmetasztázis képe látszott a medencecsontokban, ezért zoledronsavkezelés indult. Terápiás erőfeszítéseink ellenére a beteg állapota romlott, és 2019 augusztusában elhunyt.

A fenti eset több tanulsággal is szolgált. A kis biopsziás minta nem minden esetben reprezentatív a teljes tumorra nézve. Emellett szembesültünk az SCLC és az LCNEC közötti differenciáldiagnosztikai kérdésekkel. A szakirodalmi ajánlások ismertetik a két daganat közötti finom különbségeket, nemritkán azonban a morfológiai jegyek keverednek, így a kórisme felállítása nehezebbé válik. Esetünk felhívja a figyelmet arra, hogy az SCLC és az LCNEC a neuroendocrintumor-spektrum tagjai, és elkülönítésük, valamint kezelésük nem mindig egyértelmü.

\section{Megbeszélés}

A szegedi Pathologiai Intézetben a tüdőből származó minták vizsgálatakor az esetek közel egynegyedében találkozunk neuroendocrin tumorokkal. Ebben a spektrumban helyezkedik el a típusos és atípusos karcinoid, valamint az SCLC és az LCNEC. Az első három tumor sejtjeinek közös jellemzője a só és bors jellegü, finoman granulált kromatin, a láthatatlan magvacska, a trabeculákba, fészkekbe rendezett növekedés, nemritkán rozettaformációkkal. Az SCLC ezenfelül alig látható citoplazmával rendelkezik, gyakori a kiterjedt nekrózis, és magas a mitotikus aktivitás. Az LCNEC ezzel szemben inkább 
a nem kissejtes tüdődaganat (NSCLC) morfológiáját mutatja: széles citoplazmája van, a kromatin inkább habos, prominens a magvacska, a tömör sejtfészkek széli részein paliszád állásban vannak a sejtek, ugyanakkor rozettaképzés itt is előfordulhat.

Egy további fontos különbség a proliferációs aktivitás, amely mind az SCLC, mind az LCNEC esetében magas (>11 mitózis/10 NNL), míg azonban a Ki67 immunhisztokémiai festés során jelölődő sejtek aránya az SCLCnél közel 100\%, addig az LCNEC-nél 80\% körüli [2, 3]. A proliferációs aktivitás „árnyalatnyi” eltérése, valamint a morfológiai különbségek alapján az esetek egy részében el lehet különíteni az SCLC-t és az LCNEC-t. Ebben segíthetnek Nitadori és munkacsoportjának eredményei, melyek szerint a CK7 és a CKI8, valamint a béta-katenin és az E-kadherin expressziója fokozottabb LCNEC-ben [4]. Jelen tumorunk esetében az agyreszekátum igen károsodott szövetminta volt, amely alapján a neuroendocrin carcinoma áttétének kórisméje született. Nem lehetett biztonsággal eldönteni, hogy SCLC vagy LCNEC áttétéről van-e szó. A hörgőbiopsziás minta megfelelő mennyiségünek bizonyult, és kisebb volt az arteficiális károsodás foka. Ezáltal a finomabb morfológiai jegyek jobban elkülönültek, és az immunhisztokémiai reakciók figyelembevételével az LCNEC diagnózisát tudtuk felállítani.

Az LCNEC a tüdő daganatos betegségeinek 2,5\%-át adja a szegedi Pathologiai Intézet anyagában, ami a szakirodalmi adatokkal (3\%) összhangban áll. Az alacsony incidencia miatt kevés a betegség prognózisát és a kezelés lehetőségeit vizsgáló tanulmány [5]. Az LCNEC morfológiailag az NSCLC-re hasonlít, azonban agreszszív viselkedése, a gyakori és korai nyirokcsomó- és hematogén áttétképzése miatt inkább az SCLC-hez áll közelebb, és teljes túlélése (OS) kedvezőtlen (27-67\%) [5].

Rekbtman és mtsai új generációs szekvenálást alkalmazva tárták fel az LCNEC molekuláris szubtípusait, amelyekben a morfológiai és viselkedésbeli kettősség nyomon követhető. Az „NSCLC-like” szubtípus alkotta a nagyobb csoportot (56\%). Ebben a csoportban jellemző volt az STK11, KRAS, KEAP1, NFE2L2 mutációk jelenléte és az RBl és p53 mutációk hiánya. Az STKIl és KRAS mutációk eddigi tudásunk szerint a tüdőben elsősorban az adenocarcinomákat jellemezte, és SCLCben egyáltalán nem volt jelen. Ez a csoport genetikailag a tüdő-adenocarcinomával áll rokonságban, amire a csoport több mint egyharmadában észlelt fokális napszin-Aexpresszió is utalt [6].

Az „SCLC-like” csoport az LCNEC-esetek 40\%-át tette ki. Ezen esetekben az RBl és a p53 együttes mutációja van jelen, míg az STKIl és KRAS mutációk hiányoznak. További eltérésekként amplifikációt észleltek az MYCL, SOX2 és FGFRl gének esetében, illetve PTEN mutációt/vesztést is igazoltak. Ezen molekuláris eltérés mintázata az SCLC-re jellemző, azzal a megjegyzéssel, hogy az RBl és a p53 ritkán az NSCLC-knél is előfordul (6\%). Ugyanakkor a csoportban szembetûnő a
KEAP1-NFE2L2 mutációk jelenléte is mintegy 40\%ban. Ezen molekuláris eltérés jelen van a tüdő laphámcarcinomáinak többségében, ami alapján felmerül, hogy az „SCLC-like” csoport egy része genetikailag kapcsolatba hozható a laphámcarcinomákkal is. Ez utóbbi hipotézist támogatja, hogy ebben a csoportban fokális p40-expresszió volt jelen. Habár egy kisebb vizsgálatban az „SCLC-like” fenotípusú daganatok platinaalapú kemoszenzitivitása kifejezettebb volt, ezen újabban felismert molekuláris csoportok terápiát befolyásoló hatását további vizsgálatokkal kell igazolni [6].

Mivel az LCNEC ritka betegség, nehéz fázis II-III. vizsgálatokat szervezni. Emiatt korrekt, nemzetközileg elfogadott terápiás protokoll nem áll rendelkezésre, illetve az ajánlások igen sokfélék és változatosak [5].

Általában a sebészi kezelés önmagában elegendő I. stádiumú betegség esetén, azonban számos publikációban felvetették, hogy a sebészi kezelés után adjuváns kemoterápiával a betegségmentes túlélés, valamint az OS növelhető [7-16], sőt egyes szerzők már ajánlják az adjuváns kemo- és/vagy radioterápiát korai stádiumú LCNEC esetén is [8, 17-20]. Ezen eredmények megegyeznek Kujtan és munkacsoportjának tapasztalataival, akik retrospektív munkájukban a National Cancer Database-t használva 1232, I. stádiumú LCNEC-esetet vizsgáltak. Kujtan kimutatta, hogy szignifikáns különbség észlelhető az OS tekintetében azon betegcsoportok között, akik csak sebészi kezelést kaptak, és azok között, akik sebészi kezelésben és adjuváns kemoterápiában egyaránt részesültek (kizárólag sebészi OS: 47,4\%, kombinációs kezelés OS: $64,5 \%, \mathrm{p}<0,001)$ [21]. Filosso és $m$ tsai európai multicentrikus vizsgálatukban hasonlóan a kombinációs kezelés előnyeit észlelték [22].

Az amerikai National Comprehensive Cancer Network (NCCN) ajánlása szerint a stádiumspecifikus kezelésnek az NSCLC kezelési protokollját kell követnie. Ezen protokoll alapján adjuváns kemoterápia vagy kemoradioterápia adandó nyirokcsomóáttétek, inkomplett reszekció (Rl), „high grade” szövettani vélemény, $>4 \mathrm{~cm}$-es tumorméret és pleuralis érintettség (PL2-3) esetén [7].

Cattoni és mtsai túlélést befolyásoló klinikai és patológiai változókat vizsgáltak. Eredményeik alapján a korai stádiumú LCNEC eseteiben a reszekció önmagában 47,4\%-os (95\% CI: 32,3-61,1) OS-hez vezetett, és a betegek közel felében szisztémás kiújulás alakult ki. Kimutatták, hogy >3 cm-es tumorátmérő esetén szignifikánsan nagyobb a betegség kiújulásának valószínűsége, és alacsonyabb a teljes túlélési arány. Eredményeik alapján a $3 \mathrm{~cm}$-nél nagyobb, nyirokcsomó-metasztázis nélküli (pN0), kompletten reszekált (R0) LCNEC-esetekben adjuváns kemoterápia adását javasolják [7].

$\mathrm{Az}$ adjuváns terápia során alkalmazandó szereket illetően ellentmondásos ajánlásokkal találkozunk. Az amerikai NCCN az NSCLC-kezelési protokollt ajánlja az LCNEC eseteiben, melyben ciszplatin és gemcitabin vagy docetaxel vagy vinorelbin adása jöhet szóba [7]. Amint Gálffy összefoglaló dolgozatában rámutat, ha- 
zánk - az NCCN ajánlásait követve - az LCNEC kezelését alapvetően az NSCLC-séma szerint fogadja el. Ez alapján a III/A stádiumig a sebészi reszekció az első vonalbeli kezelés, amelyet a III/A stádiumban neoadjuváns kezelés egészíthet ki. Posztoperatív platinaalapú kezelés indokolt az I/B stádiumtól. III/B stádiumban konkomittáló kemoradioterápia javasolt, míg a IV-es stádiumú LCNEC esetében az első vonalban platinaalapú kemoterápia javasolt új generációs szerrel kombinálva (gemcitabin, paklitaxel, docetaxel, pemetrexed vagy vinorelbin) [23]. A szövettani kép és a betegség agresszivitása azonban sokban hasonlít az SCLC sajátságaira, emiatt számos publikáció az SCLC kezelése során használt ciszplatinetopozid adását javasolja. Sőt több publikációban arra hívták fel a figyelmet, hogy a platina és etopozid adása javította a túlélést más, a nem kissejtes tüdőrák kezelésében alkalmazott kombinációkkal szemben [17, 18, 24, 25]. A szakirodalomban található kezelési protokoll kettőssége (NSCLC- vs. SCLC-séma) a saját kezelési gyakorlatban, illetve a bemutatott esetben is tükröződik.

Az LCNEC kezelésében a radioterápia szerepe szintén vitatott. Mivel a sebészi eltávolítás kiváló lokális tumorkontrollt eredményez, illetve a kiújulás általában távoli metasztázisok formájában jelentkezik, elsősorban inkomplett reszekció és nyirokcsomóáttétek jelenléte esetén van szerepe az adjuváns radioterápiának. A kórjóslat javulását észlelték, amikor a radioterápiát oligometasztatikus betegségben alkalmazták, és kimagasló túlélésbeli javulást mutattak ki agyi metasztatikus folyamatok esetében. A profilaktikus agyi irradiáció az SCLC kezelési stratégiájának része, mivel az esetek mintegy felében agyi metasztázis fejlődik ki [26]. Rieber és mtsai publikációjukban az LCNEC eseteiben a profilaktikus cerebralis irradiáció ellen foglaltak állást. Vizsgálatukban azt találták, hogy LCNEC esetén közel 25\%-os az agyi metasztázisok kifejlődésének valószínúsége, ami megkérdőjelezi a terápia hasznosságát [27]. Ezzel ellentétben Naidoo és kutatócsoportja a IV. stádiumú LCNEC eseteinek közel felében számolt be agyi metasztázisról, ami az ilyen előrehaladott esetekben mégis felveti a profilaktikus irradiáció létjogosultságát [28].

\section{Következtetés}

Az LCNEC eseteiben igen korlátozottak a célzott kezelés lehetôségei, mivel alacsony a célozható molekuláris eltérések előfordulása. A szóba jöhető célpontok a PTEN- és az FGFRl-eltérések, amelyek a Rekhtman és mtsai által definiált „SCLC-like” csoportban voltak gyakoribbak. A szakirodalomban ismertek olyan LCNECesetek is, melyekben EGFR-aktiváló mutáció vagy ALKátrendeződés mutatható ki, és a célzott kezelés hatására szembetűnő regresszió alakult ki [29, 30], ezért vizsgálatuk az alacsony előfordulások ellenére is mérlegelendő. Rekhtman felhívta a figyelmet arra, hogy az LCNEC eseteiben igen magas a tumormutációs „burden”, ami arra utalhat, hogy PDl/PDLl „immune checkpoint” gátló kezelésre szenzitív tumorokról lehet szó [6]. A nagyobb elemszámú, prospektív kohorszvizsgálatok tervezése a jövőben megoldást jelenthet a problémára [5].

Esetismertetésünkkel, valamint a szakirodalom áttekintésével szeretnénk felhívni a figyelmet erre a ritka, de diagnosztikus és terápiás kihívásokat jelentő tüdődaganatra.

Anyagi támogatás: A kutatás és a kézirat elkészítése anyagi támogatásban nem részesült.

Szerzői munkamegosztás: Z. T.: Koncepció, adatgyüjtés, kiértékelés, a kézirat megfogalmazása. J.-N. G.: Adatgyüjtés, kiértékelés, a kézirat megfogalmazása. T. L. Koncepció, adatgyüjtés, a kézirat megfogalmazása. Cs. G., F. J., Sz. K., P. R.: Koncepció, kiértékelés, a kézirat megfogalmazása. A cikk végleges változatát valamennyi szerző elolvasta és jóváhagyta.

Érdekeltségek: A szerzőknek nincsenek anyagi érdekeltségeik.

\section{Köszönetnyilvánítás}

Köszönetünket fejezzük ki Dezső Mihálynak a szövettani képek biztosításáért.

\section{Irodalom}

[1] Zombori T, Furák J, Nyári T, et al. Evaluation of grading systems in stage I lung adenocarcinomas: a retrospective cohort study. J Clin Pathol. 2018; 71: 135-140.

[2] Travis WD, Brambilla E, Burke, et al. WHO classification of tumours of the lung, pleura, thymus and heart. Fourth edition. International Agency for Research on Cancer, Lyon, 2015.

[3] Fillinger J. Pathology of lung neuroendocrine tumors. [A tüdő neuroendokrin daganatainak patológiai diagnosztikája.] Magy Onkol. 2018; 62: 83-89. [Hungarian]

[4] Nitadori J, Ishii G, Tsuta K, et al. Immunohistochemical differential diagnosis between large cell neuroendocrine carcinoma and small cell carcinoma by tissue microarray analysis with a large antibody panel. Am J Clin Pathol. 2006; 125: 682-692.

[5] Fasano M, Della Corte CM, Papaccio F, et al. Pulmonary largecell neuroendocrine carcinoma: from epidemiology to therapy. J Thorac Oncol. 2015; 10: 1133-1141.

[6] Rekhtman N, Pietanza MC, Hellmann MD, et al. Next-generation sequencing of pulmonary large cell neuroendocrine carcinoma reveals small cell carcinoma-like and non-small cell carcinoma-like subsets. Clin Cancer Res. 2016; 22: 3618-3629.

[7] Cattoni M, Vallières E, Brown LM, et al. Large cell neuroendocrine tumor size $>3 \mathrm{~cm}$ negatively impacts long-term outcomes after R0 resection. World J Surg. 2019; 43: 1712-1720.]

[8] Veronesi G, Morandi U, Alloisio M, et al. Large cell neuroendocrine carcinoma of the lung: a retrospective analysis of 144 surgical cases. Lung Cancer 2006; 53: 111-115.

[9] Roesel C, Terjung S, Weinreich G, et al. A single-institution analysis of the surgical management of pulmonary large cell neuroendocrine carcinomas. Ann Thorac Surg. 2016; 101: 19091914.

[10] Filosso PL, Rena O, Guerrera F, et al. Clinical management of atypical carcinoid and large-cell neuroendocrine carcinoma: a multicentre study on behalf of the European Association of Tho- 
racic Surgeons (ESTS) Neuroendocrine Tumours of the Lung Working Group. Eur J Cardiothorac Surg. 2015; 48: 55-64.

[11] Sarkaria IS, Iyoda A, Roh MS, et al. Neoadjuvant and adjuvant chemotherapy in resected pulmonary large cell neuroendocrine carcinomas: a single institution experience. Ann Thorac Surg. 2011; 92: 1180-1186.

[12] Asamura H, Kameya T, Matsuno Y, et al. Neuroendocrine neoplasms of the lung: a prognostic spectrum. J Clin Oncol. 2006; 24: 70-76.

[13] Paci M, Cavazza A, Annessi V, et al. Large cell neuroendocrine carcinoma of the lung: a 10-year clinicopathologic retrospective study. Ann Thorac Surg. 2004; 77: 1163-1167.

[14] Takei H, Asamura H, Maeshima A, et al. Large cell neuroendocrine carcinoma of the lung: a clinicopathologic study of eightyseven cases. J Thorac Cardiovasc Surg. 2002; 124: 285-292.

[15] Eichhorn F, Dienemann H, Muley T, et al. Predictors of survival after operation among patients with large cell neuroendocrine carcinoma of the lung. Ann Thorac Surg. 2015; 99: 983-989.

[16] Fournel L, Falcoz PE, Alifano M, et al. Surgical management of pulmonary large cell neuroendocrine carcinomas: a 10-year experience. Eur J Cardiothorac Surg. 2013; 43: 111-114.

[17] Iyoda A, Hiroshima K, Toyozaki T, et al. Adjuvant chemotherapy for large cell carcinoma with neuroendocrine features. Cancer 2001; 92: 1108-1112.

[18] Rossi G, Cavazza A, Marchioni A, et al. Role of chemotherapy and the receptor tyrosine kinases KIT, PDGFR $\alpha$, PDGFR $\beta$, and Met in large-cell neuroendocrine carcinoma of the lung. J Clin Oncol. 2005; 23: 8774-8785.

[19] Dresler CM, Ritter JH, Patterson GA, et al. Clinical-pathologic analysis of 40 patients with large cell neuroendocrine carcinoma of the lung. Ann Thorac Surg. 1997; 63: 180-185.

[20] Rieber J, Schmitt J, Warth A, et al. Outcome and prognostic factors of multimodal therapy for pulmonary large-cell neuroendocrine carcinomas. Eur J Med Res. 2015; 20: 64.

[21] Kujtan L, Muthukumar V, Kennedy KF, et al. The role of systemic therapy in the management of stage I large cell neuroendo- crine carcinoma of the lung. J Thorac Oncol. 2018; 13: 707714.

[22] Filosso PL, Guerrera F, Evangelista A, et al. Adjuvant chemotherapy for large-cell neuroendocrine lung carcinoma: results from the European Society for Thoracic Surgeons Lung Neuroendocrine Tumours Retrospective Database. Eur J Cardiothorac Surg. 2017; 52: 339-345.

[23] Gálffy G. Diagnosis and treatment of the neuroendocrine tumors of the lung. [A tüdő neuroendokrin daganatainak diagnózisa és kezelése.] Magy Onkol. 2018; 62: 113-118. [Hungarian]

[24] Kozuki T, Fujimoto N, Ueoka H, et al. Complexity in the treatment of pulmonary large cell neuroendocrine carcinoma. J Cancer Res Clin Oncol. 2005; 131: 147-151.

[25] Yamazaki S, Sekine I, Matsuno Y, et al. Clinical responses of large cell neuroendocrine carcinoma of the lung to cisplatin-based chemotherapy. Lung Cancer 2005; 49: 217-223.

[26] Aupérin A, Arriagada R, Pignon JP, et al. Prophylactic cranial irradiation for patients with small-cell lung cancer in complete remission. N Engl J Med. 1999; 341: 476-484.

[27] Rieber J, Schmitt J, Warth A, et al. Outcome and prognostic factors of multimodal therapy for pulmonary large-cell neuroendocrine carcinomas. Eur J Med Res. 2015; $20: 64$.

[28] Naidoo J, Santos-Zabala ML, Iyriboz T, et al. Large cell neuroendocrine carcinoma of the lung: clinico-pathologic features, treatment, and outcomes. Clin Lung Cancer 2016; 17: e121el29.

[29] De Pas TM, Giovannini M, Manzotti M, et al. Large-cell neuroendocrine carcinoma of the lung harboring EGFR mutation and responding to gefitinib. J Clin Oncol. 2011; 29: e819-e822.

[30] Aroldi F, Bertocchi P, Meriggi F, et al. Tyrosine kinase inhibitors in EGFR-mutated large-cell neuroendocrine carcinoma of the lung? A case report. Case Rep Oncol. 2014; 7: 478-483.

(Zombori Tamás dr., Szeged, Állomás u. 1., 6725 e-mail: zomtam@gmail.com)

\section{"Suadere primum dein corrigere benivoli est." (Előbb tanácsot ad, csak utána igazít helyre a jóindulatú.)}

A cikk a Creative Commons Attribution 4.0 International License (https://creativecommons.org/licenses/by/4.0/) feltételei szerint publikált Open Access közlemény, melynek szellemében a cikk bármilyen médiumban szabadon felhasználható, megosztható és újraközölhetö, feltéve, hogy az eredeti szerző és a közlés helye, illetve a CC License linkje és az esetlegesen végrehajtott módosítások feltüntetésre kerülnek. (SID_1) 